\title{
Transformation, trust and the 'importance of teaching': continuities and discontinuities in the Coalition Government's discourse of education reform
}

\author{
Agnieszka Bates ${ }^{1}$
}

Department of Education, Froebel College, University of Roehampton, London, UK

The imperative of transforming education continues to permeate the discourse of UK education reform. Although the Coalition Government's publications herald a 'new school system', they reveal the same neo-liberal thinking as their New Labour predecessors. The context of the national budget deficit is now being brought to bear to promote greater effectiveness of the education system. Inherent in the Coalition strategy is a diminution of the vital role of teachers in bringing about profound change. This paper examines the notion of transformative change through the lens of George Herbert Mead's (1932, 1956) philosophy of evolution. Within this framework, transformation is a complex, emergent and unpredictable process that resists centralised control. Consequently, profound social change needs to be predicated on trust, conceptualised as a reciprocal relationship rooted in the acceptance of phenomena beyond our control.

\footnotetext{
${ }^{1}$ Email: agnieszka.bates@ roehampton.ac.uk Department of Education, Froebel College, University of Roehampton, Roehampton Lane, London SW15 5PJ
} 
Keywords: transformative change; trust; interdependence; emergence

\section{Introduction}

In May 2010, after thirteen years in power, the New Labour Party was replaced in Government by a Conservative and Liberal Democratic coalition led by David Cameron (Conservative) and Nick Clegg (Liberal Democrat). Despite promises of a 'new' education system, the first publications of the Coalition Government (Department for Education 2010a, 2010b, 2011a) reveal a number of commonalities with the New Labour discourse of reform. The compulsion to reform which, under New Labour, led to a 'policy epidemic' (Ball 2003, 215), surfaces in the Coalition discourse as statements highlighting educational improvement as an imperative. For example: 'Across the globe, governments have recognised the urgent need to improve their education systems...', 'We must reform with urgency' (DfE 2010b, 45). These statements strongly resonate with Tony Blair's mantra of 'education, education, education' on becoming Labour Prime Minister in 1997 (Alexander 2011, 73).

New Labour education reform deployed the policy levers of standards and structures (Blair 2011). Targets for driving up standards in national tests were introduced through the 'National Strategies' for Literacy and Numeracy (Department for Education and Employment 1998, 1999). Structural changes, based on an assumption that 'structures beget standards' (Blair 2011, 265), were pursued through the opening of 'academies', state-maintained schools, set up with the help of private sponsors and managed independently of local government. The case for change constructed by the Coalition Government replicates the New Labour focus on standards in the context of international comparisons, because 'what really matters is how we're doing compared with our international competitors' (DfE 2010a, 3). As 
Cameron and Clegg warn in their foreword to the White Paper 2010: 'the truth is, at the moment we are standing still whilst others race past' (2010a, 3).

New Labour and Coalition Governments' approaches to education reform are characterised by continuity in neo-liberal thinking. The neo-liberal state uses its power to protect and promote market values and extend them to non-market contexts; which is designed to develop enterprising, self-sufficient and competitive individuals (Harris 2007). Neo-liberal approaches to governance emphasise management, standardisation, performativity, bureaucratic structures and procedures, competition, cost cutting and efficiency. The damaging effects of neo-liberal thinking include an impoverished view of education, social relations viewed as relations of exchange, and the hegemony of instrumentalist reasoning. Harris (2007) emphasises that neo-liberal discourse 'holds us captive', making it difficult for us to see outside of the picture of the self-interested individual, disconnected from others and driven, ultimately, by the values of the marketplace.

A neo-liberal education system places two main demands on teacher professionalism. Firstly, it requires education to create a workforce for the marketplace, faithful to the values of consumerism and competition. The Coalition Government is repeating the New Labour mantra of the educated person as a lifelong learner, possessing transferrable skills acquired by studying economically 'useful' subjects (Leitch 2006; Department for Business, Innovation and Skills 2011). Secondly, because neo-liberalism excludes alternative discourses and requests teacher compliance, New Labour references to professional autonomy and the Coalition Government's promises of freedom for schools sound rhetorical. Whilst paying 'lip service' to the devolution of power to the 'frontline' professional, both Governments have sought to retain control through 'earned trust' (Morris 2001) 
and 'high levels of accountability' (DfE 2010a). Based on the premise that trust in others 'presupposes the freedom of action of others' (Sztompka 1999, 23), the highly centralised control of the teaching profession through accountability, standardisation, curriculum prescription and inspection regime denies teachers actual professional autonomy and freedom.

However, the transformation of UK education to a 'world class system' is not possible without trust in the professional judgement of teachers and without deeper engagement with the meaning of 'transformation' as profound change. It appears that trust as a prerequisite for educational transformation (Evans 1996) has been distorted by Morris's (2001) notion of 'earned trust' and the current Government's conception of trust predicated on 'high levels of accountability' (DfE 2010a, 8). Transformation has been narrowly defined by both Governments in terms of raising standards of pupil achievement within prescribed, unrealistic timeframes, linked to the five to sixyear electoral cycle. This could explain the urgency with which the Coalition Government is seeking transformation, as education reform is driven by political imperatives.

Where the Coalition Government is departing from previous policy is in the more radical drive towards effectiveness and simple solutions. These departures are signalled with words such as 'abolish', 'remove', 'end', 'sharply cut back', which punctuate the White Paper 2010: 'So we are reviewing all existing guidance, aiming to remove what is not necessary and sharply cut back what is left' (DfE 2010a, 31). The will to abolish and replace many of the inherited policies with 'something more effective' is presented in the document as the key approach to reform. For example, the reason for abolishing the Financial Management Standard in Schools is that 'it has become a tick-box paper exercise... We will replace it with something simpler 
and more effective' (2010a, 30). However, the Government's ambition to transform and liberate schools seems to be somewhat rushed and not thought through. For example, 'conversion to Academy status' is cast as a simple, quick solution to the problems of struggling schools, but how exactly this could happen remains unexplained:

We will... ensure that the lowest performing schools, attaining poorly and in an

Ofsted category for not improving, are considered for conversion to become Academies to effect educational transformation. (2010a, 12)

Similarly, the concept of 'freedom', or 'liberation', for schools, on condition that they meet the expected standards appears contradictory. If radical reform is at the centre of Coalition Government's vision, then this would require a radical engagement with neo-liberal values and a more dramatic departure from the New Labour standards agenda. Instead, the Coalition seems to replicate the New Labour approach to reform, albeit with the proviso that educational transformation is expected to happen more efficiently. These continuities and discontinuities will be examined from the perspective of Mead's $(1932,1956)$ philosophy of evolution, to which this paper will now turn.

\section{Social progress as emergent from mutual involvement and participation}

As a sociologist with an ambition to develop a philosophy of evolution, Mead (1956) was interested in a process-based theory of social development. His thinking is underpinned by the concepts of emergence, interdependence and diversity as constitutive of social progress. Drawing on Darwin's (1859) theory of evolution, Mead argues against the Newtonian-Cartesian view of change perceived as a 
manipulation of social structures (forms), based on a simple cause and effect type of causality which assumes that effects of change can be easily predicted. This perspective on change, Mead explains, is also contained in the Kantian view of the world as made of static forms, given in advance of experience, in the character of the mind itself. The Kantian doctrine gives rise to the subject-object distinction and a static, fixed, reified reality, where objects can be changed by the subject manipulating them. Mead $(1956,7)$ is against this 'pre-evolutionary' mechanical conception of the world, because it does not give 'any explanation to the form of things'. In contrast, Darwin's (1859) 'Origin of Species' posits that species (Latin for 'forms') arose through the life process itself, and it is this process that determines the form: 'every activity of the form altered the form itself' $(1956,9)$. In other words, the 'structure is simply something that expresses this process as it takes place' (1956, 14). In the context of social development, the processes and principles making societies progress into higher developed, more complex organisations are those of human intercommunication and participation.

Crucial to understanding these processes is the concept of interdependence, which is premised on the essential mutuality of interactions between the society and the individual. Mead argues that individual selves are being formed by and are simultaneously changing social relations:

Human society... does not merely stamp the pattern of its organized social behavior upon any one of its individual members... it also, at the same time, gives him a mind... And his mind enables him in turn to stamp the patterns of his further developing self... upon the structure or organization of human society, and thus in a degree, to reconstruct and modify in terms of his self the general pattern of social or group behaviour in terms of which his self was originally constituted. $(1956,251)$ 
Interdependence has two important implications. Firstly, by presupposing reciprocity in all social relations, it highlights the importance of democratic relationships, which 'make everyone a sovereign and everyone a subject' (1956, 274). Secondly, introducing change through social control is an unpredictable task, requiring a lot of re-adjustment, because of the reconstruction and modification of the new social pattern being introduced by each individual. Any far-reaching change requires a sharing of common interests by the individuals involved:

\footnotetext{
Any such social reconstruction, if it is to be at all far-reaching, presupposes a basis of common social interests shared by all the individual members... and it is shared by all the individuals whose minds must participate in, or whose minds bring about, that construction... $(1956,269)$
}

Reaching a shared basis of common interest is crucial, because "the changes that we make in the social order in which we are implicated necessarily involve our also making changes in ourselves' $(1956,269)$. What Mead describes here is profound social change which effects self-change as well as social development.

What is crucial in a democratic social order is diversity. This is because societies develop complexity of organisation through increasing degrees of functional, rather than class, differentiation. This differentiation emerges in the process of adaptation to the changing environment, characteristic of evolution. Also important here is that this process: 
takes now one form and now another, according to the conditions under which it is going on. That is the essential thing... the process will determine the form according to the conditions... $(1956,16)$

Evolution has no fixed long term goal beyond adapting to the changing circumstances. Instead of a blueprint, or design, the process of evolution maintains itself and is characterised by the emergence of new forms. It is emergence that 'makes an almost indefinite organization possible' $(1956,36)$, because it leads to novel elements, unknowable and undreamed of in advance.

Emergence, Mead (1932) maintains, is a difficult concept, because of its elusive, unpredictable nature and because of the way our minds work. The emergent is 'a conditioning as well as a conditioned factor' which can change the course of events and, as such, defies prediction:

...the emergent event... the occurrence of something which is more than the processes that have led up to it and which by its change, continuance or disappearance, adds to later passages a content they would not otherwise have possessed. $(1932,52)$

The difficulty we have with accepting the inability to predict all aspects of our lives is linked by Mead to 'our rationalistic natures [that] will never be satisfied until we have conceived a universe within which [events] arise inevitably out of that which preceded them' $(1932,46)$. This is underlined by a will to control:

The difficulty that immediately presents itself is that the emergent has no sooner appeared than we set about rationalizing it, that is, we undertake to show that it, or at least the conditions that determine its appearance, can be found in the past that lay 
behind it... in such a restatement of the past as conditioning of the future that we may control its reappearance. $(1932,46)$

Examined from Mead's perspective, centrally designed social reform captures us in the realm of 'forms', focusing change on structures and subject-object relationships rather than on the processes that involve participation and can therefore can lead to the emergence of the novel and the unpredicted. Reform thus conceived highlights the dynamics of intercommunication that is essential for the individual in order to integrate the social, or, in Mead's words, to 'enter into the attitude of others' $(1956,40)$. His alternative to reform through command and control, and the resulting subordination of some people by others, is 'intelligent social control', based on creating conditions which integrate instead of separating, that put individuals in relationships with others instead of being divisive. Whilst relations between capital and labour, producers and consumers, or relations in the economic community are, according to Mead, more conducive to separation rather than integration, democratic communities provide a conditioned and a conditioning environment for the emergence of social bonds:

The development of the democratic community implies the removal of castes as essential to the personality of the individual; the individual is not to be what he is in his specific caste or group as against other groups, but his distinctions are to be distinctions of functional difference... democratic consciousness is generated by differences of functions. $(1956,273)$

A conclusion arising from Mead's theory is that encouraging a process of a democratic debate about the values and directions for education, in place of a 
centrally controlled, fixed blueprint for reform, could provide an environment for an educational transformation to emerge. However, the origins of the New Labour and Coalition Governments' education discourse are located in a different paradigm. It is to this point that I now turn.

\section{'Transformation' in New Labour and Coalition Government discourse: 'the learning game' continued}

Both New Labour and Coalition Government approaches to education reform are firmly grounded in the neo-liberal 'universe of discourse' (Mead 1965, 36), which conceptualises 'transformation' in terms of raising standards. One of the architects of New Labour education reform, and one of the many 'new entrepreneurs' and 'heroes' of New Labour reform (Ball 2007, 86), was Professor Michael Barber. He was appointed in 1997 as Head of Prime Minister Tony Blair's Delivery Unit and

Chief Adviser to the Secretary of State for Education on School Standards. In 2007, as Head of Global Education Practice of McKinsey \& Company management consulting, Barber co-authored a research report on the world's best performing schools systems, the McKinsey Report (Barber and Mourshed 2007). The Coalition Government's White Paper 2010 draws heavily on the findings of the Report.

Barber's earlier book, The Learning Game: Arguments for an Education Revolution (Barber 1997), provided a rationale for the large scale reforms introduced by New Labour (Department for Education and Employment 1998; Department for Education and Skills 2004). Barber's vision of a 'revolution' in education is based on the re-engineering model, developed in the context of the corporate world as a blueprint for a 'business revolution'. The 'revolutionary' dimension to this model 
relies on a complete departure from existing practice, radical break with tradition and a switch to entirely new ways of working:

'Re-engineering a company means tossing aside old systems and starting over.'... 'Companies... see re-engineering as an opportunity to further their lead over their competitors'... those who succeed in re-engineering deliberately broke traditional rules. Assumptions which had governed the way they worked for generations were deliberately challenged and overturned. (Barber 1997, 249-251)

Here Barber is advocating harsh instrumentalism in 'tossing aside old systems' and 'deliberately breaking traditional rules' for the purpose of gaining economic competitive advantage. The licence for the designer of 'the game' to drive his game plan or agenda, to the exclusion of any other consideration, is clear in the following extract from an interview with Barber, conducted by Sarah Mead (2006). In reference to the implementation of the National Literacy Strategy (DfEE 1998) Barber stated:

...from 1997 to 1999 we went at this first phase with enormous energy and drove reform with great speed... Large-scale reform driven from the top down; designing all the materials at the national level and training everybody in a cascade out; using the accountability system to publish results and school inspection to check that people were adopting better practices. (Mead S. 2006)

The position and power of the policy maker as a detached observer, a subject manipulating resources and dismissing the 'human factor' is also apparent in the following: 
Between 2001 and 2005 what Blair increasingly hankered after was a way of improving the education system that didn't need to be constantly driven by government. He wanted to develop self-sustaining, self-improving systems, and that led him to look into how to change not just the standards and the quality of teaching, but the structures and incentives. Essentially, it's about creating different forms of quasi-market in public services, exploiting the power of choice, competition, transparency and incentives. (Mead S. 2006)

The Coalition's education reform discourse replicates the idea of self-improving systems and takes it further. For example, the proposed 'new school system' aims to accelerate New Labour's Academies initiative. In contrast to New Labour, Academy status has been envisaged by the Coalition to become the 'norm' for schools in England (Patton 2010). Consequently, schools have been encouraged to convert to Academies through financial incentives (Millar 2011). The statement that '[s]ome schools will not want to acquire Academy status just yet' (DfE 2010a, 12) implies an assumption that converting to Academies is inevitable. This is despite mixed evaluations of the New Labour Academy drive (Curtis et al. 2008). Also in alignment with New Labour levers for the self-improving system, even more information will be put 'into the public domain, so that is it possible to understand a school's performance more fully than now' (DfE 2010a, 13). This is envisaged as increasing the 'power of choice' and includes the establishment of new 'Free Schools', which will be state-funded but privately-run (Gove 2011). The drive for Academies has been characterised as a neo-liberal 'experiment' which brings the UK education reform agenda 'closer to the business agenda than it has been at any time in the past' (Ball 2007, 171). 
Both New Labour and Coalition Governments define educational transformation in terms of higher standards and increased efficiency. Targets to raise standards are presented as beyond debate, even though when they were first introduced into education with the National Literacy Strategy, the Strategy document acknowledged the scarcity of literature on target setting in education (DfEE 1998). Whether education targets work and standards have actually risen has been questioned by researchers (Stephen 2007; Smithers 2007; Fullan 2003). However, seven years into the New Labour Government, the then Education Secretary Charles Clarke made the following statement about the success of New Labour reform:

As well as transforming life-chances, our reforms have shattered myths about education and shown that it is possible to make real change and improvement quickly at every phase and stage of learning. (DfES 2004, 14)

The tight timeframes set by both Governments for educational transformation, understood as Mead's (1956) 'profound change', appear unrealistic. Although the Coalition Government has begun to acknowledge that certain changes, for example curricular reform, need a few years to embed, their overarching aim is to 'learn more quickly and systematically from good practice elsewhere' (DfE 2010a, 15). The 'new' approach to reform is informed by the McKinsey Report (Barber and Mourshed 2007), which previously also informed New Labour policy (Department for Children, Schools and Families 2007). Borrowing from 'good practice elsewhere', as recommended by the Report, is problematic in a number of ways. Firstly, it ignores environmental complexity, the unique social, economic and cultural context which is entirely different in Britain in comparison with the world's 
'best' school systems such as Finland or Singapore. Secondly, it devalues good practice in the UK. Lastly, the focus on 'good practice' can disregard important theoretical perspectives and lead to over-reliance on superficial, skills based approaches.

The contentious findings of the McKinsey Report stem from its ontological and epistemological positioning. The Report is embedded in the Newtonian paradigm which views the world as a mechanism in which change is largely reduced to simple cause and effect relationships. Barber and Mourshed emphasise in the Report that, for any school systems to stay on top, 'three things matter most: (1) getting the right people to become teachers, (2) developing them into effective instructors and, (3) ensuring that the system is able to deliver the best possible instruction for every child' $(2007,2)$. These recommendations follow a linear, simple cause-and-effect relationship, for example the cause - increased teacher effectiveness - is directly linked to the effect - improved pupil outcomes. The Report reduces pedagogy to 'appropriate instructional methods' $(2007,35)$ and teachers' quality to their level of literacy:

...studies show that a teacher's level of literacy, as measured by vocabulary and other standardized tests, affects student achievement more than any other measurable teacher attribute. $(2007,17)$

The Report constructs a competitive world which devalues tradition in pursuit of a utilitarian ideal of success in the global marketplace:

The world is indifferent to tradition and past reputations, unforgiving of frailty and ignorant of custom or practice. $(2007,6)$ 
What is of concern here is that this stark worldview is linked to the main purpose of education defined as '[c] hanging what happens in the hearts and minds of millions of children - the main charge of any school system...' $(2007,2)$. This statement echoes Margaret Thatcher's ambition for economic thinking to 'change the soul' (Ball 1999). It also resonates with Mead's $(1956,6)$ warning that the mechanical, 'pre-evolutionary' paradigm 'has no future - or a very dark one'. Viewed from Mead's (1956) evolutionary perspective, Newtonian-Cartesian thinking and the will to control which underpins the discourse of both New Labour and Coalition Governments, is unlikely to transform education. Reform is perceived here mainly as structural change, such as 'conversion to Academy status'. A change in status does not automatically ensure the profound change described by Mead as changes in our selves. The environment conducive to self-change provides opportunities for participation in dialogue and social integration and these processes are stunted by neo-liberalism. On the contrary, neo-liberal competitiveness leads to a disintegration of social bonds and a divided society (Harvey 2006). For teaching professionals these divisions are likely to be further exacerbated by the Coalition Government's blueprint for 'training our next generation of outstanding teachers' (DfE 2011a). This point provides the focus for discussion in the section below.

\section{Discontinuities in the discourse of reform and a divided profession}

In a departure from New Labour approaches, Coalition publications seem to prepare the ground for an increased differentiation within the teaching profession, with financial incentives for best graduates, especially in the shortage subjects of mathematics and science (DfE 2011a). Whilst New Labour attempted to raise the 
status of teaching through making it a Masters level profession and offered Masters courses to all teachers wishing to gain the qualification, Government funding for Masters study has now been withdrawn (Universities Council for the Education of Teachers 2011). Alternative incentives are being planned, which will be distributed according to the quality of 'teacher training institutions' and 'talent' of graduates:

We currently spend around $£ 500 \mathrm{~m}$ each year on the initial training of teachers. We should now use more of that resource to tackle the problem of shortage subjects, create stronger incentives for the most talented graduates to come into the profession and put our resources into the highest quality training institutions. (DfE 2011a, 9)

Performance-related pay is also projected in the future, as implied by the following:

We will give head teachers greater freedoms to reward good performance and address poor performance... We want to see schools making more use of existing pay flexibilities. We also wish to extend these flexibilities, so that schools can attract good graduates into the profession and reward high performance. (DfE 2010a, 25)

Proposed 'targeted bursaries' for teacher training range from $£ 20,000$ for candidates of 'outstanding potential' in high priority specialisms, to $£ 4,000$ for candidates of 'satisfactory potential' in 'other' secondary specialisms and primary (DfE 2010a, 9). 'Non-useful' secondary subjects such as art and the primary education sector are constructed here as 'low priority' and therefore deserving the lowest level of incentive. These proposals are potentially divisive. 
The White Paper 2010 condemns New Labour targets and national league tables for encouraging 'gaming behaviour', such as 'over-rehearsing tests and changing the curriculum to embrace 'equivalent' qualifications which count heavily in performance tables' (DfE 2010a, 13). However, it overlooks the possibility of 'gaming behaviour' emerging as a consequence of teachers' qualifications and performance being subject to differentiated financial rewards and incentives. Extrapolating from the definition of emergence, it is very difficult, if not impossible, to predict the exact consequences of such divisions amongst teachers. What is, however, highlighted by Mead (1956), is that social bonds emerge in communities which are highly integrated. At the individual level this means being able to empathise and connect to the attitude of others. This process can be undermined by the division between a new elite of highly paid, most 'talented' graduates and 'lower quality applicants' with Bachelor degrees (DfE 2011a, 10). On the contrary, it is common, shared interests, relational unity and more closely knit interlocking that are essential if educational community is to progress to higher stages of development. By increasing divisions within the teaching profession, the proposed changes reinforce the Cartesian notion of the independent subject, disconnected from others. On the level of professional community, this entails competition in place of collaboration and self-serving individualism instead of interdependent relationships. Paradoxically, therefore, the proposed changes are detrimental to improvement, because far reaching change is predicated on the commonality of interests shared by all individual members of a community (Mead 1956).

\section{On trust, professional freedom and standards}


The reciprocity of interdependence resonates with the mutuality of trust relations. Trust is defined by Frowe as 'a voluntary act that arises because we cannot control or guarantee to sustain all aspects of our lives, nor are all aspects of our lives predictable' $(2005,38)$. The premise of the limits to our ability to control and predict echoes Mead's (1932) concept of emergence. Trust implies also a wish to maintain a relationship: 'I trust you because your interests encapsulate mine to some extent - in particular, because you want our relationship to continue' (Hardin 2004, xix). Like interdependence, the principle of trust can also strengthen social bonds and create an environment conducive to social progress.

Even though both Governments refer to trust, they do so in the context of 'high levels of accountability', control, and scrutiny of evidence. For example, central to New Labour's vision of a remodelled teaching profession is the paradox of 'earned trust' (Morris 2001, 3). Likewise, having established the priority of 'high levels of accountability', the Coalition Government wishes teachers to 'both feel highly trusted to do what they believe is right and highly responsible for the progress of every child' (DfE 2010a, 18). Since children's progress is measured by standardised targets, 'responsibility' mentioned here amounts to accountability. Exerting control through 'high levels of accountability' implies an underlying lack of trust, for '[i]f we have absolute control over the actions of another, then there is no need to trust them, because we can be assured that the behaviour we desire will be forthcoming' (Frowe 2005, 38).

Former New Labour Education Secretary Estelle Morris (2001) asserted that 'gone are the days when a doctor or a teacher could say... 'trust me', I'm a professional', Instead she extended an offer of 'earned trust' predicated on compliance with the standards agenda and excellent performance. The White Paper 
2010 asserts authority in a number of ways, mainly through the following structure: 'this is our assessment of the situation now, this is where we want to be in the future, so we will...', which is followed by actions that will be taken. Interestingly, 'Training our next generation of outstanding teachers' is subtitled 'An improvement strategy for discussion' (DfE 2011a). However, the only discussion it opens is about 'how' to implement the detailed improvement plan: 'We want to invite views on how this might work in practice' $(2011 \mathrm{a}, 10)$. The details of the plan itself are beyond debate.

Trusting relationships cannot be earned or built on transactional, conditional or unilateral power relations. On the contrary, trust needs to be worked at, over time (Cook 2003). Fukuyama's (1995) investigation of trust highlights the human need for recognition which enhances our ability to associate, develop solidarity and build communities united by trust. This concept of trust arises in a community as a result of honest, cooperative behaviour and shared norms and goals such as religion, justice and honour. Fukuyama's analysis resonates with Mead's (1956) description of conditions for democratic organisation to emerge:

The greatest economic efficiency was not necessarily achieved by rational selfinterested individuals but rather by groups of individuals who, because of preexisting moral community, are able to work together effectively. (Fukuyama 1995, 17-21)

Conversely, the loss of trust leads to highly regulated forms of cooperation and bureaucratic management which can lead to inauthentic behaviours and 'rituals of verification' which are more costly, and therefore less effective, than trust relations (Power 1997). As Power argues, audit has replaced trust in the audit society. In the absence of trust, New Labour Government intensified managerialist measures of 
performance and methods of checking to ensure efficiency, effectiveness and quality. The Coalition Government intend to extend these measures (DfE 2010a). However, auditing is ridden with problems (Power 1997). Even though originally devised as a replacement for trust, audit itself requires trust in the auditors and in the veracity of their accounts. Power (1997) argues that auditing in this context is more about control than quality. Therefore, excessive auditing has dysfunctional side effects, such as an erosion of work relationships caused by excessive checking; creation of new mentalities and perceptions of significance and a doubt in audit accounts unless the auditors are themselves audited.

Efficient, large scale control is predicated on standardisation and accompanying reduction of quality to simple measurable characteristics, in order to make audit more feasible (Power 1997). Standardisation is thus closely linked to audit. Whether the role of standards is to lead to real improvements in quality, or to ensure the minimum acceptable level, or simply to facilitate audit and control, the effects of standardisation can be damaging. Standards might make mass production more efficient, but efficiency comes at the price of attributing value to what can be easily counted, for accounting purposes. Where disparity between word and deed appears, and a gap between politicians' promises and outcomes shows up, standards can be re-defined, outputs inflated.

Audit processes are driven by power relations, power being an 'ability to demand accounts, to exercise control over performance, while at the same time remaining unaccountable' (Power 1997, 146). Releasing teachers from surveillance and scrutiny and reinstating professional trust could diminish the current gulf between 'poorly rewarded 'doing' and highly rewarded 'observing', (Power 1997, 147). This argument is supported by Mead's (1956) notion of diversity perceived as a 
functional, rather than class, differentiation. Class differentiation arises out of power inequalities in which one gets the sense of one's self by feeling superior to others. Functional differentiation is based on competence that gives the individual a position in which he can realise himself in the community. Functional differentiation is predicated on simultaneously being a 'subject' and a 'sovereign':

One is to be a subject to the degree that he is a sovereign. He is to undertake to administer rights and maintain them only insofar as he recognises those rights in others. $(1956,274)$

It is the emergence of this awareness that to affect means also to be affected which constitutes for Mead an evolution of individual consciousness that is simultaneously a conditioning and conditioned factor of profound social progress. This is because 'social reconstruction and self or personality reconstruction are the two sides of a single process - the process of human social evolution' $(1956,270)$. What this insight means in the context of education is that, for transformation to emerge, policy makers' will to control needs to be superseded by the will to connect and engage in genuine dialogue with teachers. The democratic-dialogic process which, in Mead's analysis, determines the form, could be conducive to the emergence of novel approaches to education reform. The novel is impossible to emerge in the command and control approach of both New Labour and Coalition Governments. The over-prescribed, highly regulated policies that subordinate teachers into implementation have two negative consequences. Apart from an erosion of trust relations, they also preclude the kind of transformation which could emerge from a dialogic process involving teachers; after all teaching professionals 
are functionally more expert in education than policy makers. In the Mead paradigm, with its assumptions about diversity and interdependence, this dialogue would respect the mutual involvement of teachers and policy makers in the process of reforming education and would therefore seek to avoid different voices merging into a single dominant discourse.

\section{Conclusion}

As we face another wave of education reform, with the new Coalition Government legislating 'new' solutions to enduring problems and safeguarding transformation through high levels of accountability, a question arises as to whether what is deemed a quick solution today, may be a source of tomorrow's problems. Transformation defined as raising standards in order to gain a competitive advantage in the global economy constitutes just one conception of educational and social progress. The economic imperative offers a narrow view of human behaviour driven primarily by self-interest in order to maximise material well-being. By constructing all social relations as transactions of exchange, the economic discourse erodes social bonds and democratic values. In Mead's analysis, it is not self-interest, but selfdevelopment that, over time, enables the individual and the society to evolve into more complex and sophisticated levels of organisation. In Coalition Government's analysis, the context of the current economic crisis is brought to bear on the introduction of 'radical reform', which can perhaps improve effectiveness in the short term, but which can also lead to, as yet unforeseen, consequences in the future.

Within Mead's $(1932,1956)$ framework the essence of educational and any other social activity is not efficiency, effectiveness, profit maximisation, or competitive advantage, but the diversity and richness of human interactions. Outcomes and 
targets cease to be valid measures of success, what counts instead is the quality of human relationships, which make individuals and societies evolve in nonstandardised, diverse and unpredictable ways. However challenging, Mead's 'philosophy of evolution' may be offering us an alternative to delivering education out of the grip of neo-liberalism. One of the many possibilities offered by his thinking is to accept that to speak of transformation is to transcend the logic of control and incrementally added value, to aim at profound change. As speaking about 'reform' and 'transformation' tends to capture us in the realm of forms, to aim at transformation is to deliberately abandon a focus on structures and fixed blueprints for change in favour of creating an environment conducive to the processes of intercommunication and building democratic relationships. These processes require a lot of mutual re-adjustment and 'intelligent social control' that accepts uncertainty. Accepting ambiguity might allow us to return the notion of trust to its roots in the acceptance of the phenomena beyond our control.

\section{Notes on contributor}

Agnieszka Bates is a Senior Lecturer in Leadership and Management and Professional Practice in the Department of Education, University of Roehampton. Her research interests include leadership and management, education governance and education policy discourse. 


\section{References}

Alexander, R. 2011. Legacies, Policies and Prospects: one year on from the Cambridge Primary Review. Forum 53, no. 1: 71-92.

Ball, S.J. 1999. Global Trends in Educational Reform and the Struggle for the Soul of the Teacher! http://www.leeds.ac.uk/educol/documents/00001212.htm.

Ball, S.J. 2003. The teacher's soul and the terrors of performativity. Journal of Education Policy 18, no. 2: 215-228.

Ball, S.J. 2007. Education plc: Understanding private sector participation in public sector education. Oxon: Routledge.

Barber, M. 1997. The Learning Game: Arguments for an education revolution. London: Indigo.

Barber, M. and M. Mourshed. 2007. How the world's best performing school systems came out on top. London: McKinsey \& Company.

Blair, T. 2011. A Journey. London: Arrow Books.

Curtis, A., Exley, S., Sasia, A., Tough, S. and G. Whitty. 2008. The Academies programme: Progress, problems and possibilities: A report for the Sutton Trust. London: Institute of Education.

Department for Children, Schools and Families. 2007. The Children's Plan: Building brighter futures.

https://www.education.gov.uk/publications/standard/publicationDetail/Page1/00999/CPS.

Department for Education. 2010a. The Importance of Teaching: The Schools White Paper 2010. http://www.ictliteracy.info/rf.pdf/Schools-White-Paper2010.pdf.

Department for Education. 2010b. The Case for Change. http://publications.education.gov.uk/.

Department for Education. 2011a. Training our next generation of outstanding teachers: An improvement strategy for discussion. London: Crown, Copyright.

Department for Business, Innovation and Skills. 2011. Higher Education: Students at the Heart of the System. Norwich: The Stationery Office. 
Department for Education and Employment. 1998. The National Literacy Strategy: Framework for Teaching. London: DfEE Publications.

Department for Education and Employment. 1999. The National Numeracy Strategy: Framework for Teaching Mathematics. London: DfEE.

Department for Education and Skills. 2004. Five Year Strategy for Children and Learners. Norwich: The Stationery Office.

Evans, R. 1996. The Human Side of School Change: Reform, Resistance and the Real-life Problems of Innovation. San Francisco: Jossey-Bass.

Frowe, I. 2005. Professional Trust. British Journal of Educational Studies 53, no. 1: 34-53.

Fukuyama, M. 1995. Trust: the social virtues and the creation of prosperity. London: Penguin Books Ltd.

Fullan, M. 2003. Change forces with a Vengeance. London: RoutledgeFalmer.

Gove, M. 2011. Michael Gove's speech to The Policy Exchange on Free Schools. http://www.education.gov.uk/inthenews/speeches/a0077948/michael-goves-speech-to-thepolicy-exchange-on-free-schools.

Hardin, R. 2004. Trust and Trustworthiness. New York: Russell Sage Foundation.

Harris, S. 2007. The Governance of Education: How neo-liberalism is transforming policy and practice. London: Continuum.

Harvey, D. 2006. Neo-liberalism as creative destruction. The Annals of the American Academy of Political and Social Science 2007, 610, no 1: 21-44. http://ann.sagepub.com/content/610/1/21.full.pdf+html.

Leitch, S.L. 2006. Leitch Review of Skills: prosperity for all in the global economy - world class skills. Final report. http://www.hm-treasury.gov.uk/d/leitch_finalreport051206.pdf.

Mead, G.H. 1932. The Philosophy of the Present. New York: Prometheus Books.

Mead, G.H. 1956. On Social Psychology. Chicago: Chicago University Press.

Mead, S. 2006. Education Reform Lessons from England: An Interview with Sir Michael Barber. http://www.educationsector.org/publications/education-reform-lessons-england. 
Millar, F. 2011. Schools start to question wisdom of rushing to convert to academy status. Education Guardian. 11 January. http://www.guardian.co.uk/education/2011/jan/11/schools-academystatus-incentives.

Morris, E. 2001. Professionalism and Trust - The future of teachers and training. http://education.guardian.co.uk/print/0,3858,4298852-107365,00.html.

Patton, G. 2010. Michael Gove: academies will be norm in England. The Telegraph. 27 May. http://www.telegraph.co.uk/journalists/graeme-paton/7767664/Michael-Gove-academieswill-be-norm-in-England.html.

Power, M. 1997. The Audit Society: Rituals of Verification. Oxford: Oxford University Press.

Smithers, A. 2007. Blair's Education: an international perspective. http://suttontrust.com/reports/SuttonTrust_BlairsEd19June.pdf.

Stephen, M. 2007. Standards and Structures: Improving the quality of teaching in English schools. http://www.reform.co.uk/Research/Education/EducationArticles/tabid/110/smid/378/ArticleI D/623/reftab/71/Default.aspx.

Sztompka, P. 1999. Trust: a sociological theory. Cambridge: Cambridge University Press.

Universities Council for the Education of Teachers. 2011. UCET concerned at withdrawal of funding for master's degrees for teachers. http://www.ucet.ac.uk/2789. 